\title{
Pre-empting the arrival of a dark lord
}

Sir - In a recent leading article, "Obstacles of nomenclature", you scolded certain molecular biologists "whose profligate and undisciplined labelling is hampering communication" (Nature 389, 1; 1997). As our laboratory is responsible for some of the "offending gene names", I feel compelled to set the record straight.

The names with which I wish to take issue are a group of Drosophila genes: numb, prospero, inscuteable (not "inscrutable" as you had it) and miranda. These genes are involved in asymmetric cell division. The leading article complained that the names of the genes give no indication that they are involved in such functions. The reason is quite simple: when this group of genes was first named, nobody had any inkling that they had anything to do with asymmetric cell division.

Traditionally, a newly discovered Drosophila gene is named by the discoverer(s) according to its mutant phenotype noted then. Of this group of genes, the first was discovered in 1989. T. Uemura in our laboratory identified mutant flies that have only about 10 per cent of the normal number of sensory neurons. These mutants presumably receive much reduced sensory input and so we named the gene numb. The next one in the group, prospero, was named by C. Doe and M. Scott in 1991. One of the phenotypes of prospero loss-of-function mutants is a change of cell fate. Doe and Scott decided to name that gene after the main character in Shakespeare's The Tempest because of Prospero's presumed ability to influence fate. It was not until 1994 that we first realized that numb is involved in asymmetric cell division.

Later, the work of several laboratories demonstrated the involvement of prospero and inscuteable in asymmetric cell division. In the case of prospero, it was not difficult to imagine that the segregation of a nuclear protein to a crescent on the cell membrane before cell division is reminiscent of Prospero's exile to an island. It therefore seems appropriate to name a protein that associates and localizes Prospero after Miranda, his daughter and companion in exile.

You may then ask why the people in the field didn't get together and rename the genes to reflect their roles in asymmetric cell division? There are good reasons not to do so.

First, it is an excellent tradition among Drosophila workers that once a gene is named the name stays. This tradition has been followed for many decades with only rare exceptions. This allows subsequent workers to pay homage to earlier workers and prevents the possibility of a dark lord coming along and renaming genes, thereby confusing future generations into thinking of him as the discoverer of everything.

Second, an important lesson from modern biology is that the action of a gene is often pleiotropic. A gene is often used at multiple developmental stages for different functions. For example, prospero is not only involved in asymmetric cell division but also has an important function in controlling axon growth and guidance. If one were to rename prospero to reflect its role in asymmetric cell division, one would ignore the other, equally important, function. Moreover, our knowledge of a gene changes with time. It is not uncommon to discover a completely new and unsuspected function for an old familiar gene. Do we then rename a gene every time we learn something new about it? Of course not. We revise and update the knowledge associated with the gene.

Does the naming system of Drosophila genes hamper communication? I don't think so. Perhaps it is in the nature of human memory that many biologists (not just Drosophila workers) find it easier to remember and associate the individual, sometimes whimsical, Drosophila gene names with their function than to keep track of the differences between $u n c-37$ and unc-39 of Caenorhabditis elegans or between $c d c 24$ and $c d c 42$ of Saccharomyces cerevisiae even though, in the latter cases, workers in the field have adopted a more systematic naming system. Many of us were glad that C. Nüsslein-Volhard and E. Wieschaus chose whimsical names such as armadillo and hedgehog (instead of gap-1, pair-rule-2, segment polarity-3 and so on) for the genes they discovered in their historical screen for Drosophila body patterning mutants. This system works well enough that a similar naming system has been adopted for zebrafish genetics.

Finally, I wish to quibble with two more points in your leading article. You say: "the lack of a common classical education explains today's avoidance of the archaic but otherwise constructive habit of giving new things names that have a Latin or Greek etymology. The consequence has been a descent into whimsy. Murray GellMann started it all with his quark.... There are two problems with these statements. Cultural chauvinism notwithstanding (one man's classical education is another man's low-level baloney), for the reasons already stated, I don't see how naming things with Latin or Greek origins would help in the case of Drosophila gene names. And it is ironic that you juxtaposed Gell-Mann with "lack of classical education". Of all the twentieth-century physicists, Gell-Mann is probably the last person one would have thought of as having a "lack of classical education".

You also say: "Regrettably, molecular biologists have followed the particle physicists' whimsy with obscurantist enthusiasm." Don't blame it on the particle physicists. Drosophila geneticists already used whimsical names before "three quarks for muster Gell-Mann or three aces for $\mathrm{Mr}$ G. Zweig".

\section{Yuh Nung Jan}

HHMI Research Laboratories,

University of California

School of Medicine,

Parnassus and Third Avenues, U-426,

San Francisco, California 94143-0724, USA

e-mail:ynjan@itsa.ucsf.edu

\section{There are 'two cultures'}

Sir — David Edgerton is wrong, and C.P. Snow was right (Nature 389, 221; 1997). Every scientist knows people thoroughly versed in literature, music and the arts who are proud not to understand mathematics, physics and chemistry, do not comprehend the scientific process, have no idea of what is going on in the scientific world and are unable to follow the instructions for use of a video recorder. That science and technology play such an important role in our life is no proof that this abyss does not exist, but shows only that science and technology make our lives easier, and that the economy can grow only by creating new products based on science and technology.

To deny that there are strong antiscientific currents in our society is to shut our eyes to the broad resistance against, for example, necessary animal experiments, or gene technology for agriculture. In a scientifically minded society, it would be impossible for astrology and other esoteric practices to flourish.

The 'two cultures' are not a British phenomenon but can be found equally in other European countries, particularly Germany and Austria.

Friedrich Katscher

Mariahilfer Str. 133,

A-1150 Vienna, Austria 